\title{
TUTELA INIBITÓRIA DE OFÍCIO: TÉCNICA PROCESSUAL DE PROTEÇÃO AO MEIO AMBIENTE DO TRABALHO
}

\section{Fausto Siqueira Gaia ${ }^{1}$}

\section{Resumo}

O presente artigo científico analisará a tutela inibitória, como técnica processual para a proteção do meio ambiente de trabalho, considerando a natureza metaindividual do direito material tutelado e a condição de hipossuficiência do empregado. A partir da fixação da natureza jurídica instrumental do processo, a pesquisa cingirá à investigação da possibilidade jurídica de concessão, de oficio, de tutela inibitória para a proteção do meio ambiente de trabalho. Para tanto, serão analisados os fundamentos de direito material e de direito processual que autorizam a utilização desta técnica processual.

Palavras-chave: Tutela inibitória; Ex-officio; Meio Ambiente do Trabalho

\section{INTRODUÇÃO}

A globalização da economia e a massificação dos conflitos sociais vêm gerando diversas alterações nas organizações empresariais. Estas modificações diretamente implicam a geração de impactos nas relações de laborais havidas entre empregados e empregadores e entre estes e a sociedade na qual a empresa está inserida.

A busca pela ampliação de espaço na sociedade globalizada exige a reorganização das atividades negociais, com o objetivo de redução dos custos de produção e, assim, permitir uma maior competitividade no mercado de consumo. A eficiência dessas atividades econômicas, com o incremento dos lucros, muitas vezes é permitida a partir da redução dos custos de produção e por meio da precarização das condições de trabalho, especialmente no campo das normas de segurança e medicina de trabalho.

A opção do empresário pela infração de normas de proteção à higidez do meio ambiente de trabalho é estimulada pelos elevados dispêndios envolvidos no cumprimento das normas de segurança do trabalho. Impera ainda a quase certeza de impunidade no descumprimento desse direito fundamental, já que apenas parcela dos trabalhadores ingressa com ações trabalhistas durante a vigência da relação laboral. Acresce-se a tais circunstâncias

\footnotetext{
1 Doutorando em Direito do Trabalho pela Pontifícia Universidade Católica de São Paulo (PUC/SP). E-mail: faustogaia@yahoo.com.br
} 
o número reduzido de ações fiscalizatórias promovidas pelos auditores fiscais do trabalho.

O sistema processual pátrio contempla inúmeras técnicas processuais para a tutela de direitos metaindividuais. É apresentada, no âmbito processual, a tutela inibitória como uma das técnicas positivada para garantir a eficácia social do direito fundamental previsto no inciso XXII do artigo $7^{\circ}$ da Constituição da República de 1988 e, desta forma, assegurar ao trabalhador um meio ambiente de trabalho saudável.

A busca pela efetividade do direito fundamental ao meio ambiente de trabalho saudável deve nortear a conduta do magistrado trabalhista na sua atividade diária. Diante de conflitos de interesses submetidos à apreciação e julgamento, ainda que apresentados de forma individualizada, deve se valer o órgão julgador de técnicas processuais disponibilizadas pelo ordenamento jurídico para assegurar o intento de entregar de forma efetiva e tempestiva a prestação jurisdicional. Apresenta-se, assim, a tutela inibitória de ofício, como um dos instrumentos abalizados pelo sistema jurídico para a tutela desses interesses que transcendem o campo individual.

O presente artigo, a partir do método dedutivo, oferecerá resposta ao seguinte problema: quais são os fundamentos e os limites da atuação jurisdicional no processo construtivo da norma jurídica, que autorizam a concessão da tutela inibitória de ofício, com o objetivo de assegurar a efetividade do direito fundamental ao meio ambiente de trabalho saudável?

\section{A TUTELA INIBITÓRIA COMO TÉCNICA PARA A TUTELA DE DIREITOS METAINDIVIDUAIS}

O paradigma do Estado liberal é marcado pela intervenção mínima na esfera de liberdade individual por parte do Estado. Este ponto caracterizador impactou não apenas a interpretação dos direitos fundamentais, tendo reflexos diretos na elaboração e na interpretação das normas de direito adjetivo.

A preocupação do legislador processual neste cenário está adstrita à formulação de regras que impactam minimamente na esfera de liberdade individual. A construção processual, neste sentido, é voltada a elaboração de textos normativos associados a tutelas repressivas, desvinculadas da ideia de prevenção de ilícitos.

Este modelo processual foi impactado pela multiplicação de demandas individuais, ainda que o direito material fosse compartilhado por uma coletividade. O reconhecimento destes novos direitos, que extrapolam a esfera individual, exige, no cenário do Estado democrático de Direito, a preocupação com a tutela preventiva de direitos.

Surge, assim, a necessidade de reavaliar a efetividade do modelo processual fundado na tutela repressiva. Além deste ponto, serão analisados a seguir os fundamentos para uma tutela preventiva de direitos.

\section{Inefetividade da tutela repressiva}


Quando se analisa a tutela de um bem jurídico, a primeira ideia que se apresenta está relacionada à noção de prevenção, especialmente quando se trata de bens de cunho não patrimonial ou mesmo aqueles que assumem expressão para além das pessoas, individualmente consideradas.

A atividade preventiva de lesões ou de danos a direitos, no âmbito das relações de emprego, ocorre tanto de forma administrativa, quanto judicialmente. $\mathrm{Na}$ esfera fiscalizatória, a atividade apresenta-se ineficaz, em decorrência do número insuficiente de auditores fiscais do trabalho para realizar a fiscalização de todas as empresas instaladas no Brasil $^{2}$ e da carência de recursos materiais necessários para a execução de tais tarefas.

Revelando-se insuficiente a atividade preventiva administrativa, abre-se um campo vasto e fértil para violações de direitos de trabalhadores. A lesão de bens jurídicos de trabalhadores implica o desequilíbrio das relações sociais, gerando conflitos de interesses que acabam por desaguar no Poder Judiciário.

Certo, porém, é que, das demandas ajuizadas, expressivo é o número daquelas que são propostas individualmente por trabalhadores que têm os seus contratos de trabalho já encerrados (FAVA, 2008, p. 85). Outro ponto característico dessas reclamações trabalhistas individuais é representado pela dedução de pretensões de cunho repressivo e sancionatório, de efeito econômico (PISANI, 1976, p. 314), ou seja, após a ocorrência do dano, especialmente em matéria de segurança e medicina do trabalho.

A tutela repressiva, nestes casos, não se apresenta como instrumento apto à proteção de determinados direitos, especialmente aqueles de expressão metaindividual, quando se observa o processo sob a perspectiva da efetividade do direito material. Acrescentam-se ainda às dificuldades apresentadas pela tutela repressiva, o fato de que, em se tratando de violações a direitos relacionados à matéria de segurança e medicina do trabalho, eventuais danos causados aos trabalhadores podem ser insuscetíveis de restauração integral do status quo (MOREIRA, 1988, p. 24).

Isso implica, além de reflexos na esfera individual, como, por exemplo, a redução da capacidade laborativa, as aposentadorias precoces e o acometimento de doenças ocupacionais permanentes (OLIVEIRA, 2007, pp. 31-32), influências na coletividade como um todo, já que o seguro social certamente será acionado, aumentando, assim, o propalado déficit da Previdência Social.

Especialmente no âmbito das relações de emprego, a prestação da jurisdição por meio de tutelas

\footnotetext{
${ }^{2} \mathrm{O}$ número de auditores fiscais de trabalho no Brasil é insuficiente para a realização de atividades preventivas e de fiscalização quanto ao descumprimento de normas trabalhistas, conforme dados divulgados na Portaria no 98, de 30 de janeiro de 2015 do Ministério do Trabalho e Emprego, que apresentou os resultados de desempenho da Auditoria-Fiscal do Trabalho para o ano de 2014. Na Portaria no 98, em referência, são apontados os números da fiscalização, que totalizaram 607.348 ações fiscalizatórias, considerando o universo de 90 milhões de pessoas ocupadas no período, segundo o sítio do IBGE (http://www.ibge.gov.br/home/estatistica/indicadores/trabalhoerendimento/pme_nova/defaulttab_hist.shtm), em pesquisa realizada em 17 de abril de 2017, às 9 h.
} 
repressivas, normalmente apresentadas sob a provocação individual do trabalhador lesado, implica a delimitação do alcance prático da decisão às partes do litígio, não alcançando terceiros que tenham os contratos de trabalho até então vigentes.

Essa circunstância revela que, diante de restrições processuais, como os limites subjetivos da coisa julgada material, a tutela repressiva não tem o condão de inibir a repetição do dano a outros trabalhadores, em semelhantes situações jurídicas. Sobre a ineficiência coletiva de uma tutela repressiva contra atos danosos já consolidados, leciona Pimenta Freire que:

o problema da insuficiência de uma tutela essencialmente repressiva e ressarcitória no campo de direitos de dimensão coletiva muitas vezes de estatura fundamental, não patrimoniais e insuscetíveis de quantificação em termos monetários, impondo-se a adoção de novas formas mais variadas e eficazes de provimento, tais como os de caráter antecipatório, preventivo ou inibitório e de natureza mandamental. (PIMENTA, 2009, p. 23)

Associam-se, ainda, aos reflexos nas ordens material e processual dos envolvidos, o fato de que a insuficiência da tutela repressiva pode também representar verdadeiro estímulo ao descumprimento de normas sociais básicas por parte dos detentores dos meios de produção. Estes reflexos impactam diretamente o sistema concorrencial, implicando até mesmo a competitividade desleal de mercado com aqueles empregadores que cumprem as obrigações trabalhistas (PIMENTA, 2004, pp. 199-255).

Os institutos processuais cunhados em uma perspectiva liberal devem ser reinterpretados à luz da transcendência coletiva do direito material subjacente. Diante da preocupação preventiva na tutela de direitos, no paradigma do Estado democrático de Direito, instrumentos processuais positivados no ordenamento jurídico pátrio devem revisitados e reanalisados, sob uma ótica preventiva de direitos e não apenas sob a perspectiva repressiva, como no modelo liberal clássico.

Assim, técnicas processuais como a antecipação dos efeitos da tutela, as medidas cautelares, as tutelas de evidência, as ações cominatórias e as tutelas preventivas inibitórias, dentre outras, vem sendo desenvolvidas e aperfeiçoadas pelo legislador, pela doutrina e pela jurisprudência como instrumentos idôneos a assegurar a efetividade processual, a tutela efetiva do direito material e a minimização dos efeitos danosos do tempo sobre os direitos substantivos.

De toda a sorte, diante da delimitação do escopo do trabalho, será feito a análise da tutela inibitória, sem prejuízo de eventual realização de referências às demais técnicas preventivas de lesões a direitos quando necessárias ao desenvolvimento do trabalho.

\section{Os fundamentos para uma tutela inibitória preventiva}

A tutela inibitória é concebida como espécie de tutela preventiva de direitos materiais (SUAREZ, 2013, 
p. 290), cuja possibilidade de apreciação judicial recebe fundamento de validade no princípio da inafastabilidade do controle jurisdicional, positivado no artigo $5^{\circ}, \mathrm{XXXV}$ da Constituição. Não apenas as lesões, mas também as ameaças a direitos podem ser levadas ao conhecimento e à apreciação do Poder Judiciário.

A natureza fundamental do princípio da inafastabilidade do controle jurisdicional implica o reconhecimento de um novo papel do Estado, que deve se preocupar não apenas com a restituição ao status quo de lesões já consolidadas, mas, sobretudo, para evitar a ocorrência de ilícitos. Resta então superada, no atual paradigma do Estado democrático de Direito, a visão do modelo liberal de que a atividade preventiva de direitos realizada pelo Poder Judiciário é também violadora de outro princípio de igual envergadura fundamental: o da liberdade individual e empresarial.

A preocupação com a liberdade, em seus diversos matizes, especialmente as de iniciativa e de organização produtiva no âmbito laboral, não pode servir de escudo para a atuação judicial preventiva, até mesmo porque o princípio constitucional da legalidade, previsto no mesmo artigo $5^{\circ}$ da Constituição, que também serve como balizador da esfera de atuação empresarial, impõe o cumprimento dos ditames legais em sentido amplo.

Se não bastasse, ao se conceber o acesso à justiça em uma perspectiva preventiva (CAPPELLETTI; GARTH, 1998, p. 68), assegura-se, em se tratando de direitos com expressão metaindividual, a proteção reflexa não apenas daqueles que manejam individualmente suas demandas, podendo incluir terceiros.

Além dos fundamentos constitucionais, aponta Aldo Frignani (1974, p. 457), no direito italiano, que o fundamento da tutela preventiva inibitória é a própria tutela cautelar, positivada no texto do artigo 700 do código de processo civil italiano. Sustenta que tanto na tutela cautelar quanto na tutela inibitória traz em si intrinsecamente embutida a noção de uma tutela preventiva contra atos ilícitos, decorrente do princípio geral de prevenção. A adoção da tutela preventiva inibitória está fundada no próprio poder geral de cautela concedido pelo legislador ordinário.

Esse posicionamento sofre críticas na própria doutrina italiana, como se observa nas considerações apresentadas por Cristina Rapisarda (1987, p. 113). A principal delas diz respeito ao fato de que, ao se conceber esse fundamento, estaria por via oblíqua desnaturando o próprio provimento cautelar, que é marcado pela instrumentalidade e pela não satisfatividade, ao contrário do provimento inibitório que é essencialmente satisfativo.

Embora o posicionamento de Aldo Frignani seja alvo de críticas, o mesmo não deve ser totalmente abandonado. A noção geral de prevenção, subjacente nas tutelas cautelares, serve como fundamento processual para a adoção tutelas inibitórias de ofício, como será tratado e aprofundado em momento posterior deste trabalho.

No caso do Brasil, especificamente, essa discussão sobre o fundamento infraconstitucional da tutela inibitória se revela de certo modo estéril. O sistema jurídico processual pátrio contempla expressamente nos 
artigos 497 e 536 do novo CPC e 84 do CDC os fundamentos e mecanismos para a tutela inibitória, a partir das tutelas de obrigações de fazer e de não fazer.

A tutela inibitória tem por escopo conformar o comportamento e a atuação do indivíduo, de modo que a evitar a existência de um ilícito. Diante do escopo de adequação comportamental, tendente a exigir o cumprimento de deveres jurídicos ou de obrigações de ordens legal, convencional ou contratual, tem-se que a imposição de obrigações de fazer e não fazer constituem os meios mais adequados para a concepção de uma tutela preventiva.

Segundo Arenhart (2003, pp. 219-220), essa modalidade de tutela demanda a adoção de procedimento célere, por meio da técnica da sentença mandamental, e com a possibilidade de adoção de medidas satisfativas de forma antecipada ao contraditório, diante do risco da ocorrência do dano ou da própria evidência do ilícito.

Para a tutela preventiva antecipada, inclusive pode-se valer o magistrado de tutelas antecipadas satisfativas, seja quando haja a probabilidade do direito e o perigo de dano ao resultado útil do processo. Para tanto, o novo Código de Processo Civil autoriza no artigo 294 a concessão de tutela de urgência, tanto de forma cautelar quanto antecipada, de modo a assegurar a efetividade do provimento jurisdicional futuro. Arruda Alvim (2012, pp. 868-869), nesse sentido, ainda na égide do CPC de 1973, reconhece a existência de poderes oficiais do juiz, que autorizariam a própria satisfatividade da tutela preventiva de direitos.

O primeiro questionamento que se apresenta, acerca da possibilidade de utilização da técnica processual prevista nos artigos 497 do novo CPC e 84 do CDC para a tutela preventiva de direitos, diz respeito ao fato de já existirem lesões ou danos consolidados pela prática de ato ilícito.

Trilhando conclusões semelhantes àquelas apresentadas por Arenhart (2003, pp. 226-227), há que se conceber a tutela inibitória de forma independente ao elemento dano, já que essa forma de tutela objetiva tanto a prevenção de um ilícito ainda não ocorrido quanto evitar a sua reincidência, por meio das denominadas tutelas inibitórias primária e secundária, respectivamente.

Essa peculiaridade da tutela inibitória merece consideração não apenas por questões acadêmicas, mas, sobretudo, em razão de consequências na esfera prática, notadamente na seara processual. Ao se conceber a possibilidade de concessão de tutela inibitória, independentemente da existência de dano, basta apenas à parte da demanda narrar a possibilidade de lesão a direito, em razão de conduta omissiva ou comissiva do devedor da obrigação, para que possa ser obtida a proteção judicial do interesse.

A prova da existência de dano, portanto, é irrelevante para fins de concessão ou não da tutela inibitória. Basta apenas para a sua concessão, para tanto, a prova da conduta ilícita do agente capaz de gerar apenas a potencialidade de lesão ao direito material.

O mesmo raciocínio é aplicado quanto à verificação e à comprovação do elemento culpa ou dolo do 
agente. A tutela inibitória, por possuir característica intrínseca de prevenção do ilícito, dispensa para a sua concessão a prova desses elementos subjetivos do agente, até mesmo porque o dano sequer pode ter ocorrido no momento da propositura da demanda (RAPISARDA, 1987, p. 89).

Esses aspectos, quais sejam a desnecessidade da ocorrência do dano e da prova de culpa ou dolo do agente, revelam-se importantes e se coadunam com o próprio escopo fundamental da tutela inibitória, que é o de evitar danos futuros. Nesse sentido, as lições de Marinoni são precisas:

A tutela inibitória é uma tutela específica, pois objetiva conservar a integridade do direito, assumindo importância não apenas porque alguns direitos não podem ser reparados e outros não podem ser adequadamente tutelados através da técnica ressarcitória, mas também porque é melhor prevenir do que ressarcir, o que equivale a dizer que no confronto entre a tutela preventiva e a tutela ressarcitória deve-se dar preferência à primeira. (MARINONI, 2012, p. 33)

Além disso, como já referido anteriormente, a tutela inibitória também pode revelar a eficácia preventiva nas situações em que já tenha ocorrido o dano ou lesão ao bem jurídico. As situações envolvendo obrigações de trato sucessivo ou mesmo deveres jurídicos (TALAMINI, 2001, p. 127), como são aquelas vividas durante a relação de emprego, são bastante férteis a ensejar a utilização da técnica da tutela inibitória secundária, pois o dano pode vir a se repetir no futuro em relação aquele empregado, individualmente considerado, quanto à coletividade.

Outra questão que se coloca também em relação aos pressupostos da tutela inibitória diz respeito à necessidade de prova da existência de conduta ilícita do agente para o manejo dessa técnica de tutela preventiva. A essência da tutela inibitória é a busca da prevenção, donde se conclui que o principal objetivo em seu manejo é evitar a lesão de determinado bem jurídico.

Acentua Arenhart (2003, p. 230) que, embora não se exija a existência de um dano consolidado, é necessário que a parte demonstre, ainda que por indícios, a ameaça de lesão a um bem jurídico, por descumprimento de um texto de norma contratual, legal ou mesmo convencional, de forma a obter a resposta jurisdicional. Nessa mesma linha, precisas são os ensinamentos de Spadoni:

Esta seriedade da ameaça, a justificar o provimento inibitório, deve ser revelada com a demonstração de que o réu tenha realizado ou está realizando atos que indicam, de forma razoável, uma futura violação do direito do autor, sejam esses atos preparatórios, sejam atos anteriormente praticados, e cuja probabilidade de continuação ou repetição é evidenciável. (SPADONI, 2007, p. 51)

Novamente, tais fundamentos transcendem a importância meramente acadêmica do ponto colocado, e assumem relevância no campo do direito processual. A simples comprovação, por meio de elementos indiciários, de uma ameaça de lesão a direito pela parte deve ser suficiente para o órgão julgador conceder a tutela inibitória, pois o que se tem em mente com a concessão da tutela inibitória é a prevenção de um dano ao bem jurídico.

Não se pode exigir da parte a prova robusta da conduta ilícita, até mesmo porque as obrigações e os deveres jurídicos subjacentes devem ser adimplidos espontaneamente por aqueles que têm o dever legal, 
contratual ou convencional de observar. Esperar da parte a produção de prova firme da conduta ilícita, pode provocar em razão da dificuldade probatória, inclusive em relação ao tempo despendido para tanto, a ocorrência do dano que se quer evitar com a medida preventiva.

Com maior razão, se restar evidenciada a lesão ao direito, inclusive na situação de ser incontroversa a prática do ilícito, por reconhecimento do agente causador, ou se fundado em prova documental irrefutável, por exemplo, não há porque se impedir a concessão de tutela inibitória em razão da evidência, de forma definitiva ou até mesmo em sede de antecipação dos efeitos da tutela.

A tutela inibitória é uma tutela diferenciada (ARMELIN, 1992, p. 46) de proteção de direitos. Esta particularidade decorre tanto em razão da possibilidade de antecipação dos seus efeitos, pela urgência ou pela evidência, bem como pela plasticidade dos meios colocados à disposição do julgador para estimular o cumprimento da tutela mandamental imposta no título judicial. Dentre estes instrumentos podem ser elencados multas, interdições, dentre outros meios coercitivos, que inclusive podem ser impostos independentemente de requerimento da parte, consoante autorizações previstas nos artigos 497 do novo CPC e 84 do CDC.

Fixadas as bases legais para o reconhecimento da tutela preventiva inibitória, é possível extrair as formas de sua manifestação pelo órgão judicial. Não resta a menor dúvida de que a tutela inibitória tanto pode ser concedida mediante imposição no comando sentencial de deveres de fazer e quanto de não fazer (MARINONI, 2012, p. 106), já que os próprios dispositivos infraconstitucionais mencionados fazem referência expressa a tais espécies obrigacionais.

E nem poderia ser diferente. Ao se conceber a atividade preventiva judicial, tem-se em mira evitar a ocorrência, repetição ou mesmo a continuidade de um ato ilícito. Esse ato pode ser oriundo de condutas tanto comissivas ou quanto omissivas por parte do agente.

Assim, para impor a inibição e, consequentemente, a prevenção de um ilícito, pode-se valer o órgão judicial da imposição de um fazer, quando a atitude omissiva do agente implicar a potencialidade de dano, ou de um dever de abstenção ou de tolerância, quando a atitude ativa ou o fazer do agente apresentar risco de criar dano a um bem ou interesse jurídico.

\section{ASPECTOS PROCESSUAIS PARA A ATUAÇÃO DE OFÍCIO DO PODER JUDICIÁRIO}

$\underline{\text { A atuação ex-officio do órgão julgador é medida excepcionalmente aceita em razão da necessidade de }}$ assegurar a efetividade da prestação jurisdicional. A utilização da técnica processual da tutela inibitória de ofício deve ser precedida do pleno exercício do direito ao contraditório e da ampla defesa, até mesmo para que se evite a 
arguição de nulidade processual por cerceio do direito de defesa ou questionamentos sobre a própria imparcialidade do órgão julgador.

Além desse aspecto relativo às garantias fundamentais processuais envolvidas na concessão da tutela inibitória de ofício, igualmente se revela importante analisar aspectos processuais outros envolvidos na utilização desta técnica processual. A seguir, além das garantias constitucionais do contraditório e da ampla defesa, serão analisados aspectos relativos aos princípios da instrumentalidade das formas, da economia e da celeridade processual, este último como vertente do princípio da duração razoável do processo.

\section{O contraditório e a ampla defesa}

A CRFB assegurou, no artigo 5o, LV, a garantia aos litigantes, tanto nos processos judiciais quanto administrativos, do exercício do contraditório e da ampla defesa. Essas garantias fundamentais têm como objetivo a garantia da igualdade entre as partes da demanda, permitindo que estas possam exercer de forma plena os direitos de ação e de defesa, a partir do prévio conhecimento dos elementos de fato e de direito em discussão na lide.

Nelson Nery Júnior, em trabalho sobre os princípios processuais na Constituição, preceitua que o direito ao contraditório deve ser compreendido em duplo viés, como sendo:

(...) a necessidade de dar conhecimento da existência da ação e de todos os atos do processo às partes, e, de outro, a possibilidade de as partes reagirem aos atos que lhe sejam desfavoráveis. Garantir-se o contraditório significa, ainda, a realização da obrigação de noticiar (Mitteilungsplicht) e da obrigação de informar (Informationsplicht) que o órgão julgador tem, a fim de que o litigante possa exteriorizar suas manifestaçōes. (NERY JUNIOR, 2010, pp. 210-211)

Diante desse conceito, que conjuga dois aspectos relacionados à publicidade dos atos processuais, é possível concluir que a garantia constitucional em análise está relacionada tanto à relação havida entre as partes da demanda quanto ao liame que estas mantêm com o órgão jurisdicional.

Ao se assegurar às partes o pleno exercício do direito ao contraditório e à ampla defesa, dando-lhes ciência para manifestação sobre os atos praticados pelo adversário e pelo juiz no processo e oportunidade para produção de provas, garante-se a própria segurança jurídica nas relações processuais. Além do aspecto relacionado à ciência bilateral dos atos praticados no processo, destaca Antônio do Passo Cabral (2010, p. 207) que a garantia do contraditório deve ser lida também de modo a representar no direito moderno a expressão do dever de colaboração das partes com o próprio Juízo.

Nesse aspecto, ao se dar ciência dos atos processuais que são praticados, devem as partes, em uma atividade de contribuição com a Justiça, trazer todos os elementos que possam conter subsídios para o julgamento da demanda. O contraditório e a ampla defesa representam, a partir de todas as perspectivas apresentadas, 
mecanismos constitucionais de legitimação da própria decisão judicial, pois permitem as partes trazer aos autos elementos aptos a formar a convicção do juiz.

Quando se analisa a atuação de ofício do magistrado, ou seja, de forma independente à existência de prévia provocação das partes, o exercício do contraditório e da ampla defesa deve ser plenamente assegurado, sob pena de possível caracterização de nulidade processual, se a abreviação do procedimento causar algum prejuízo a um dos demandantes.

Por outro lado, ao ser dada ciência bilateral prévia as partes do objeto da investigação realizada pelo órgão julgador, permite-se às mesmas a produção de elementos de prova e a manifestação sobre esses dados investigados. É assegurada, desse modo, a possibilidade do autor e do réu trazerem aos autos do processo elementos de convicção para o órgão julgador, o que implica o reconhecimento da validade do julgamento, ainda que de forma extra petita ou ultra petita.

No sentido de reconhecer a higidez processual, apresentam-se as lições de Bedaque, quando trata dos efeitos decorrentes da inobservância do princípio da correlação entre o objeto da demanda e o objeto da decisão, quando observadas as garantias do contraditório e da ampla defesa:

Se atentarmos para a razão maior da vedação, lícito será afirmar que, se a matéria foi submetida ao contraditório e à ampla defesa, concedendo-se às partes todas as oportunidades para produzir prova a respeito, o vício concernente à técnica processual não constitui óbice à participação. Assegurou-se a efetivação do contraditório e da ampla defesa. Nessa medida, o vício decorrente da violação da regra técnica, consistente na adstrição do provimento à demanda, pode ser relevado. Isso porque restou preservado o escopo desejado pelo legislador ao enunciá-la. (BEDAQUE, 2002, p. 35)

A correta identificação da demanda, por meio dos seus elementos constitutivos, é garantia que a parte tem de conhecer os pontos que serão discutidos no processo e, assim, exercer o direito ao contraditório e à ampla defesa. Dessa forma, a atuação ex-officio do magistrado, em extravasamento dos limites definidos na lide, deve ser tida como excepcional, somente se justificando quando o interesse tutelado e as circunstâncias da situação concreta ultrapassarem os interesses das próprias partes individualmente consideradas.

As discussões envolvendo a proteção do meio ambiente do trabalho, ou seja, relacionadas aos direitos metaindividuais de natureza indisponível, justificam, diante do caso, a superação dos limites subjetivos e objetivos da demanda. Essa superação se justifica ainda mais quando outros trabalhadores estiverem em igual condição de vulnerabilidade, mas que, pelo receio do desemprego e de outras retaliações, deixam de promover o ajuizamento de reclamações trabalhistas.

Diante da situação concreta, onde há a discussão sobre o cumprimento de obrigações relativas à segurança e medicina do trabalho, ou seja, de normas de interesse público, é perfeitamente possível conceber a construção da norma jurídica que autorize a concessão de ofício de uma tutela mandamental preventiva inibitória, 
ainda que a demanda seja individualmente proposta e tenha como objeto imediato a dedução de pretensão de naturezas condenatória e ressarcitória de efeito pecuniário.

Entretanto, a atuação jurisdicional para além dos limites da demanda, por meio de adoção de tutelas preventivas de ofício, como a tutela inibitória, deve ser obrigatoriamente precedida da observância de outros princípios e garantias também de envergadura constitucional, como a do contraditório e da ampla defesa, de forma conferir validade e legitimidade à atividade protetiva.

\section{A instrumentalidade das formas e o princípio da ausência de declaração de nulidade sem prejuízo}

A preocupação do processo moderno está relacionada não apenas à correção na aplicação do direito material à situação concreta, mas, sobretudo, por garantir a efetividade da decisão e em um lapso temporal razoável. Demandas que se eternizam no tempo são incapazes de promover a Justiça, já que muitas vezes a demora da resolução do conflito é favorável ao devedor do direito e permite a consolidação de lesões.

Diante da inter-relação entre a materialização do julgado no campo fático e o tempo processual dispendido, o princípio da instrumentalidade das formas ganha expressão e relevo. Uma das expressões do princípio da instrumentalidade é a técnica da instrumentalidade das formas, ou seja, o aproveitamento de atos processuais praticados que atinjam a finalidade do instituto processual.

Na perspectiva da técnica da instrumentalidade das formas (DINAMARCO, 2013, p. 177), os institutos processuais são mecanismos postos pelo legislador ordinário para assegurar a aplicação do direito material à situação concreta, quando não houver o adimplemento espontâneo pelo devedor da obrigação ou o cumprimento do dever jurídico que a lei impõe. A perspectiva instrumental do processo está, portanto, associada ao elemento finalístico, ou seja, ao escopo de pacificação dos conflitos sociais.

Diante do aspecto instrumental do procedimento, se o ato processual praticado alcançar a sua finalidade inexiste razão para determinar a sua repetição. Antônio do Passo Cabral nesse ponto destaca que "o princípio justifica-se na ideia de que a forma não tem importância absoluta, não se podendo sacrificar a marcha processual por irregularidade formal sem antes examinar as 'finalidades do ato"'. (CABRAL, 2010, p. 44)

A necessidade de aferição das finalidades do ato revela que o princípio da instrumentalidade das formas está vinculado a outro elemento de igual densidade normativa no processo civil, qual seja o da ausência da declaração de nulidade sem a prova da existência do prejuízo.

O artigo 277 do novo CPC positivou a regra de que a adoção das formas para a prática dos atos processuais deve ser tomada de forma relativizada. Nesse sentido, no caso de realização de julgamentos extra 
petita ou mesmo ultra petita, como são aqueles que ampliam o objeto da lide para incluir provimento jurisdicional preventivo inibitório de ofício, a declaração da invalidade do ato processual somente se faz impositiva se houver a existência de prejuízo àquele a quem a decisão foi desfavorável.

A aferição do prejuízo com a decisão, que deixou de observar uma forma prescrita, deve ser vista no aspecto processual e não quanto ao resultado material do processo em si, se de improcedência ou de procedência, total e parcial. Melhor explicando, a avaliação do prejuízo processual é verificada em cotejo com a finalidade do ato do processo praticado. Haverá vício na prolação de sentença ultra petita ou extra petita se a parte for surpreendida com um comando decisório que trouxer em sua fundamentação elementos que deixaram de ser discutidos na lide pelas partes.

Se a parte, por outro lado, tiver tido ciência do objeto de investigação, sendo-lhe franqueada a manifestação em contraditório e a produção de elementos probatórios para a formação da convicção do órgão julgador, ainda que o resultado de mérito seja desfavorável, inexiste razão, diante da inexistência de prejuízo processual, para se extirpar o capítulo da sentença que avançar nos limites objetivos e subjetivos da lide.

Não há que se falar, ainda, em qualquer nulidade em decorrência de suposta ausência de imparcialidade do órgão julgador, ante a inobservância do princípio da congruência. Como já foi afirmado, a garantia do exercício do contraditório e da ampla defesa assegura que as partes possam participar ativamente do processo, inclusive na formação da convicção do órgão julgador. Não haveria, assim, qualquer surpresa das partes no julgamento, capaz de gerar o questionamento da imparcialidade do prolator da decisão.

O órgão julgador deve ter sempre em mente que o processo é apenas um instrumento para a realização do direito material e não um fim em si mesmo. A adoção da forma pela forma, desvencilhada do aspecto central de realização do direito material, transforma o processo "num desinteressante sistema de formalidades e prazos" (BEDAQUE, 2003, p. 13), como já ressaltado em diversas partes desse trabalho.

Portanto, a declaração de nulidade processual deve ser tomada como medida excepcional, que deve ser avaliada sempre à luz da existência ou não de prejuízo processual para a parte com o ato praticado.

\section{A economia processual e a duração razoável do processo}

A sociedade pós-moderna é marcada pela massificação dos conflitos, que repercutem em dados estatísticos consolidados pelo CNJ, que revelam a elevada taxa de congestionamento do Poder Judiciário, especialmente na fase de execução, com a explosão de demandas individuais condenatórias e ressarcitórias, com efeitos pecuniários.

Como visto nos tópicos anteriores, as demandas condenatórias de ressarcimento econômico do prejuízo 
não representam técnicas efetivas para a solução das crises de direito metaindividuais (MANCUSO, 2011, p. 109), pois são incapazes de restaurar o status a quo, têm alcance restrito às partes da demanda e não geram no devedor qualquer efeito educativo.

As consequências da violação desses direitos metaindividuais, no campo do processual, são verificadas na disseminação de demandas individuais condenatórias ressarcitórias repetitivas, que tornam a resposta do Estadojuiz cada vez mais morosa diante da explosão dos conflitos massificados. A preocupação do processo pósmoderno está relacionada à justiça da decisão, que passa, além da busca pela efetividade, em um provimento jurisdicional com celeridade.

Seguindo essa tendência, inclusive já reconhecida no plano internacional desde 1969, com o advento do Pacto de São José da Costa Rica, o constituinte derivado, a partir da Emenda Constitucional no 45, elevou à categoria de garantia fundamental o princípio da duração razoável do processo, assegurando meios para a celeridade da sua tramitação.

Sobre esse princípio fundamental, Nelson Nery Junior (2010, p. 319) aponta que o mesmo apresenta dupla função. A primeira delas está relacionada diretamente ao tempo do processo, desde a data do ajuizamento da demanda até o momento do trânsito em julgado e uma segunda ligada à adoção de mecanismos alternativos para a solução dos conflitos.

No entanto, esse princípio deve ser compreendido de forma ampliada. Em primeiro lugar, a duração do processo deve ser medida não apenas na fase de cognição, como pode sugerir a limitação até o trânsito em julgado, mas também de forma a considerar eventual fase de execução do processo, já que somente com a efetiva entrega do bem da vida ao credor do direito material ter-se-á a completa entrega da prestação jurisdicional.

Além disso, outro reparo que merece ser feito às considerações trazidas pelo processualista paulista diz respeito ao fato de que as funções do princípio da duração razoável do processo compreendem, além daquelas já apresentadas, também a necessidade de releitura dos institutos processuais, de modo a conferir, a partir do caráter instrumental, uma maior efetividade prática para o direito adjetivo.

Diretamente associado a essa perspectiva dos efeitos do tempo, apresenta-se o princípio da economia processual. Por meio desse princípio balizador, a prestação jurisdicional deve produzir o máximo de resultados práticos com o menor dispêndio econômico possível (LEITE, 2007, p. 67).

A justificativa de uma tutela preventiva inibitória de ofício pauta-se tanto na busca pela economia processual, quanto aos efeitos reflexos que serão gerados para as outras demandas em tramitação no Poder Judiciário trabalhista. Em relação a esses efeitos, tem-se que o acolhimento da perspectiva de atuação jurisdicional preventiva ex-officio, por meio da técnica da tutela inibitória, implica a possibilidade de aproveitamento de atos processuais praticados, de provas produzidas, de custos com a contratação de advogados, sem que haja a 
necessidade de proposituras de novas demandas individualizadas.

Por sua vez, havendo a redução das demandas individuais massificadas, será possível atender em relação aos demais conflitos uma resposta mais célere, em atendimento à garantia fundamental da duração razoável do processo.

\section{O direito à higidez do meio ambiente de trabalho e os fundamentos materiais para a sua proteção}

O sistema jurídico, nas lições de Canaris (2012, p. 280), representa uma "ordem axiológica ou teleológica de princípios jurídicos gerais", o que implica o reconhecimento de abertura ao próprio direito em si. Essa abertura do sistema é capaz de justificar a alteração de paradigmas interpretativos ao longo da história.

No cenário do Estado democrático de Direito, os princípios assumem posição destacada na atividade interpretativa, superando o papel ocupado no modelo liberal de servir como mera fonte supletiva para ocupar lacunas do direito positivo.

No âmbito do direito do trabalho, o princípio da proteção tem posição de destaque como vetor interpretativo, além de outras funções como a de inspiração ao legislador, a de suprimento de lacunas e de sistematização do ordenamento jurídico. Para a nossa finalidade, consistente na releitura de institutos do direito processual, a função interpretativa dos princípios ganhará maior espaço, diante da necessidade de conferir ao processo maior efetividade.

O princípio da proteção ou protetivo é entendido como sendo aquele que tem como finalidade corrigir as desigualdades materiais havidas entre os polos da relação da relação empregatícia, concedendo ao hipossuficiente econômico uma superioridade jurídica.

O princípio protetivo, cujo fundamento de validade é encontrado no caput do artigo $7 \mathrm{~T}^{\circ}$ da CRFB, assume diversas vertentes no plano material do direito do trabalho, manifestando na atividade interpretativa por meio da aplicação de outros princípios como norma mais favorável, do in dubio pro misero e da condição mais benéfica.

Todas essas manifestações do princípio protetivo permitem a construção de referências ao aplicador do direito. A proteção ao trabalhador é o vetor que deve nortear não apenas a interpretação do direito material, mas também a atividade jurisdicional, inclusive na aplicação de institutos e das técnicas processuais positivadas na situação concreta (BEBBER, 1997, p. 78), sempre tendo em vista a efetividade dos direitos fundamentais.

É impossível conceber a proteção integral do trabalhador ao se aplicar uma técnica processual civil, como a tutela inibitória, seguindo os mesmos princípios e parâmetros aplicáveis às relações privadas, ou seja, entre 
aqueles que ocupam, em tese, igualdade de situação jurídica.

A partir do texto constitucional, que elevou à categoria de direito fundamental social a proteção ao meio ambiente do trabalho, exsurge a necessidade de compreender os institutos processuais, que objetivam uma tutela preventiva de direitos dos hipossuficientes econômicos, como o exemplo da tutela inibitória, de forma a atender ao ideal de proteção plena. Portanto, a perspectiva de proteção ao trabalhador deve servir o princípio em análise de vetor de irradiação no procedimento tendente a concretizar o direito fundamental ao meio ambiente do trabalho saudável.

Ao se pensar em uma tutela preventiva de direitos, a perspectiva de proteção ao trabalhador deve balizar a atividade de concretização do direito. Essa atividade de interpretação e de aplicação do direito à situação concreta, jungida pelo ideal protetivo, passa pela mitigação de dogmas processuais, como, por exemplo, a observância dos princípios da adstrição e da congruência por parte do julgador.

Além disso, foi elencado pela Constituição, dentre os direitos fundamentais sociais, o direito à proteção ao meio ambiente de trabalho saudável. A importância alcançada por esse direito é tamanha que o próprio constituinte inseriu a proteção do meio ambiente do trabalho como uma questão de saúde pública, como se observa na dicção do artigo 200, VIII do texto constitucional.

Ao ser tratado o meio ambiente físico do trabalho como direito fundamental, restou também garantida, por força do parágrafo primeiro do artigo $5^{\circ}$ da Carta Magna, a sua aplicação imediata. A fundamentalidade do direito ao meio ambiente do trabalho saudável também tem o condão de servir como limite material ao exercício do poder constituinte derivado, já que representa cláusula pétrea imposta pelo constituinte originário.

Todas essas características relacionadas a esse direito fundamental representam o caráter de indisponibilidade absoluta e de importância que esse direito adquire no sistema constitucional brasileiro. Esse grau de indisponibilidade irradia-se no âmbito privado, servindo como limitador à autonomia da vontade das partes, inclusive quando manifestada de forma coletiva, por meio de convenções e acordos coletivos de trabalho firmados pelos sindicatos de classe.

O meio ambiente do trabalho, considerado pelo constituinte originário espécie do gênero meio ambiente $^{3}$, é definido por Mancuso como sendo o "habitat laboral', isto é, tudo que envolve e condiciona, direta e indiretamente, o local onde o homem obtém os meios para prover o quanto necessário para a sua sobrevivência e desenvolvimento, em equilíbrio com o ecossistema”. (MANCUSO, 1999, p.59)

Diante do conceito apresentado, a noção de meio ambiente do trabalho está relacionada à interação indissociável entre aqueles que executam diuturnamente a atividade laborativa e o local onde esta é desenvolvida.

\footnotetext{
${ }^{3} \mathrm{Na}$ forma do artigo 200, VIII, da CRFB.
} 
O aspecto apresentado tem grande valia na presente investigação científica, pois permite reconhecer que o ambiente de trabalho é o local compartilhado não apenas por um trabalhador de forma isolada, mas, sobretudo, por todos aqueles que possam, em momento atual ou futuro, interagir com aquele espaço de produção, em maior ou menor intensidade.

O ambiente de trabalho, nesse sentido, deve ser concebido de forma indivisível, considerando a perspectiva daqueles que nele laboram, embora eventuais danos causados aos trabalhadores, decorrentes da inobservância das regras de proteção por parte dos detentores dos meios de produção, possam a ser individualizados por diversos elementos circunstanciais, como, por exemplo, a extensão do dano, a condição pessoal do trabalhador, o tempo de exposição a agentes nocivos à saúde, dentre outros fatores.

A tutela do direito fundamental ao meio ambiente do trabalho assume, considerando todos os aspectos subjetivos e objetivos acima mencionados, uma dimensão metaindividual coletiva, quando analisada na perspectiva de prevenção de lesões, em razão da indivisibilidade do objeto tutelado e também na perspectiva dos sujeitos envolvidos.

É impossível reconhecer, sem ferir o princípio da isonomia, a proteção de determinados trabalhadores em detrimento dos demais, ainda mais se considerar a circunstância especial vivida na relação de trabalho de que o medo do desemprego e de retaliações restrinja às reclamações trabalhistas ao momento posterior à extinção do contrato de trabalho.

Sobre a necessidade da atuação jurisdicional de interesses metaindividuais, que diversas vezes sequer são levados ao conhecimento do Poder Judiciário, Ada Pellegrini Grinover (1984, pp. 88-89) aponta que os conflitos devem solucionados de modo macroscópico e não apenas de forma pulverizada, como hoje se observa no número crescente de demandas ajuizadas de forma individual. A atuação coletiva permite que aqueles possíveis afetados com a conduta antijurídica possam a ter o seu interesse tutelado, sem o temor de futuras retaliações por parte dos empregadores.

Embora as demandas coletivas sejam instrumentos adequados sob a perspectiva processual para a tutela dos interesses coletivos em sentido amplo, já que constituem ações "sem rosto", conforme feliz expressão de Marcos Neves Fava (2008, p. 85), é verificado diuturnamente no cotidiano forense que o seu manejo tem destaque em uma perspectiva repressiva em detrimento no viés preventivo.

Diante dessa realidade, e considerando a natureza indivisível e metaindividual do meio ambiente do trabalho, compete ao intérprete autêntico no Estado democrático de Direito aplicar as técnicas processuais disponibilizadas pelo ordenamento jurídico, como a tutela inibitória, com o objetivo de prevenção coletiva de lesões.

A demanda que versa na causa de pedir sobre violações ao direito fundamental ao meio ambiente de 
trabalho saudável, ainda que tenha sido apresentada de forma individualizada e com a dedução de pretensões de cunho reparatório e prestacional em pecúnia, é passível de gerar um provimento jurisdicional coletivo e preventivo, considerando a indivisibilidade e a natureza metaindividual do objeto da lide.

Assim, em sendo verificado em Juízo, após ser assegurada a garantia fundamental do contraditório e da ampla defesa, que de fato havia o descumprimento das obrigações referentes à manutenção da higidez no ambiente de trabalho por parte daquele réu e, diante da indivisibilidade do meio ambiente do trabalho, do elemento protetivo do trabalhador, da característica da ultrapetição trabalhista, é perfeitamente possível gerar um provimento jurisdicional preventivo e com o espectro de abrangência coletiva.

Portanto, diante da indisponibilidade absoluta desse direito fundamental, associado ao fato de que o meio ambiente laboral constitui objeto indivisível diante da dimensão coletiva, o tratamento judicial a ser conferido, quando houver discussão na situação concreta envolvendo o cumprimento de normas de segurança e medicina do trabalho, deve extrapolar os limites subjetivos e objetivos da demanda.

Além da natureza metaindividual do direito ao meio ambiente de trabalho, devem ser observados os princípios da prevenção e da precaução com outro fundamento para a concessão de tutela inibitória de ofício.

Os princípios da precaução e da prevenção não se confundem, embora ambos tenham como escopo fundamental a preocupação em evitar futuros danos ao meio ambiente, seja ele classificado, consoante a natureza jurídica do bem tutelado, em natural, artificial, cultural, do patrimônio genético e do trabalho.

O princípio da precaução tem como marca característica incidir sempre que o elemento incerteza quanto à potencialidade em si da ocorrência do dano estiver presente, a partir de uma conduta a ser praticada (LOPES, 2010, p. 103). Quer-se evitar, portanto, a partir do princípio da precaução a existência de eventual risco futuro ao meio ambiente, protegendo as futuras gerações.

Esse princípio geral de direito ambiental decorre e tem seu fundamento de validade na própria Constituição que, no artigo 225, caput, traz expressamente a intenção do constituinte de proteção das gerações futuras. No ordenamento jurídico pátrio, o princípio da precaução assumiu lugar de destaque a partir da Conferência Rio 92. A Declaração do Rio, fruto da conferência realizada na década de 1990, traz expressamente o princípio da precaução positivado em seu item 15 , que merece ser transcrito diante da sua importância:

Com o fim de proteger o meio ambiente, o princípio da precaução deverá ser amplamente observado pelos Estados, de acordo com suas capacidades. Quando houver ameaça de danos graves ou irreversíveis, a ausência de certeza científica absoluta não será utilizada como razão para o adiamento de medidas economicamente viáveis para prevenir a degradação ambiental.

Além do princípio da precaução, que tem assento quando houver a incerteza da existência de futuro dano ao meio ambiente, assume também destaque, quando se estuda a proteção de futuros danos ambientais, o princípio da prevenção. O princípio da prevenção tem campo de incidência diferenciado em relação ao princípio 
da precaução. O princípio da prevenção é aplicado, segundo Paulo de Bessa Antunes (2011, p. 50), em situações de "impactos ambientais já conhecidos e dos quais possa, com segurança estabelecer um conjunto de nexos de causalidade que seja suficiente para a identificação dos impactos futuros mais prováveis".

Diante do espectro de abrangência do princípio da prevenção, tem-se que sua aplicação cinge-se a situações nas quais os riscos de dano ao meio ambiente são previsíveis e são objetivamente conhecidos por certeza científica, diante da conduta a ser praticada pelo agente.

A utilização da tutela inibitória de ofício para a proteção do meio ambiente de trabalho tem fundamento tanto no princípio da precaução, quanto no axioma da prevenção do dano ambiental.

A omissão do empregador ao não fornecer equipamentos de proteção individuais adequados para a neutralização de agentes insalubres, além de outras infrações às normas regulamentadoras do MTE, especialmente as que versam sobre ergonomia, trabalho seguro, dentre outras tantas normas de segurança, permite ao magistrado do trabalho, conhecedor da potencialidade de riscos futuros, valer-se do princípio da prevenção para determinar a adoção de medidas adequadas a eliminar o risco de dano.

Além disso, diante da necessidade de proteção integral da saúde e da integridade do trabalhador, é possível também, por meio da utilização do princípio da precaução, adotar medidas tendentes a evitar danos, ainda que haja incerteza da potencialidade de ocorrência.

\section{CONSIDERAÇÕES FINAIS}

As dificuldades práticas para garantir a efetividade das decisões, associada a um novo perfil de demandas de uma sociedade permeada com conflitos massificados, aumentando as taxas de congestionamento do Poder Judiciário trabalhista, implicaram uma nova negação do modelo anterior de atuação jurisdicional, marcada pelos aspectos da individualidade e da função repressiva da tutela.

A ordem do dia passou a ser ditada pela preocupação preventiva de lesões aos direitos fundamentais, principalmente dos vulneráveis econômicos, como os trabalhadores, que são alijados por circunstâncias fáticas, como o risco de desemprego e de sofrerem retaliações, de postularem em Juízo, durante a vigência do contrato de trabalho, direitos sonegados por seus empregadores.

A centralidade do texto constitucional, fundada na positivação das garantias e dos princípios do acesso à justiça amplo, do contraditório e da ampla defesa, da duração razoável do processo, da proteção ao trabalhador, da proteção ao meio ambiente de trabalho saudável, da prevenção e da precaução autoriza e legitima, agora em perspectiva pós-positivista, a atividade criativa do magistrado do trabalho, preocupado com a promoção dos direitos fundamentais sociais dos trabalhadores, sem se desvencilhar do ideal da segurança jurídica. 
A técnica processual da tutela inibitória é apresentada como instrumento disponibilizado pelo legislador ordinário idôneo a reduzir as demandas individualizadas e pulverizadas, sejam nas ações individuais ou nas coletivas propostas por legitimados extraordinários.

A preocupação constitucional com a prevenção do dano em vez da repressão compensatória do ilícito, especialmente quando estão envolvidos direitos fundamentais de natureza metaindividual de hipossuficientes, como o direito à proteção ao meio ambiente do trabalho saudável, confere legitimidade ao processo de adaptação judicial de mecanismos e técnicas processuais já positivados, de modo a garantir que esses instrumentos sejam realizadores do direito material.

Daí porque é possível conceber, desde que observada a garantia do contraditório e da ampla defesa, a construção da norma jurídica que, diante da situação concreta, autorize a concessão, para além do pedido e da causa de pedir, de tutela condenatória mandamental inibitória ex-officio, de modo a constranger o empregador a observar para todos os trabalhadores o cumprimento das normas de segurança e de medicina do trabalho.

A síntese dialética, no cenário do pós-positivismo, é marcada pela possibilidade dada ao magistrado do trabalho de criar normas jurídicas de índole processual, como a tutela inibitória de ofício, que assegurem a efetividade dos direitos fundamentais, como o direito ao meio ambiente do trabalho saudável.

A adoção desse procedimento permite conceber um sistema processual preocupado com a efetividade do direito material, com reflexos diretos na redução de reclamações trabalhistas no âmbito do Poder Judiciário envolvendo violações individuais de normas de segurança e de medicina do trabalho.

\title{
INJUNCTIVE CRAFT PROTECTION: PROCESSUAL PROTECTION TECHNIQUE FOR THE ENVIRONMENT OF WORK
}

\begin{abstract}
The present scientific article will analyze the inhibitory guardianship as procedural technique for the protection of the working environment, considering the metaindividual nature of the supervised material right and the condition of hyposufficiency of the employee. Given the instrumental legal nature of the process, the research problem will be limited to investigating the legal possibility of granting, on its own, an injunction to protect the working environment. In order to do so, we will analyze the grounds of substantive law and procedural law that authorize the use of this procedural technique.
\end{abstract}

Keywords: Inhibitory protection; Ex-officio; Labor Environment 


\section{REFERENCIAS}

ALVIM, Arruda. Manual de direito processual civil. 15. ed. rev. e atual. São Paulo: Revista dos Tribunais, 2012.

ANTUNES, Paulo de Bessa. Direito ambiental. 13. ed. rev. e atual. Rio de Janeiro: Lumen Juris, 2011.

ARENHART, Sérgio Cruz. Perfis da tutela inibitória coletiva. São Paulo: Revista dos Tribunais, 2003.

ARMELIN, Donaldo. Tutela jurisdicional diferenciada. Revista de Processo, São Paulo, ano 17, n. 65, p.45-55, jan./mar. 1992.

BEBBER, Júlio César. Princípios do processo do trabalho. São Paulo: LTr, 1997.

BEDAQUE, José Roberto dos Santos. Direito e processo: influência do direito material sobre o processo. 3. ed. rev. e ampl. São Paulo: Malheiros, 2003.

Os elementos objetivos da demanda examinados à luz do contraditório. In.: CRUZ E TUCCI, José Rogério; BEDAQUE, José Roberto dos Santos (coords.). Causa de pedir e pedido no processo civil: questões polêmicas. São Paulo: Revista dos Tribunais, 2002.

CABRAL, Antônio do Passo. Nulidades no processo moderno: contraditório, proteção da confiança, validade prima facie dos atos processuais. 2. ed. Rio de Janeiro: Forense, 2010.

CANARIS, Claus-Wilhelm. Pensamento sistemático e conceito de sistema na ciência do direito. 5. ed. Lisboa: Fundação Calouste Gulbenkian, 2012.

CAPPELLETTI, Mauro; GARTH Bryant. Acesso à justiça. Tradução de Ellen Gracie Northfleet. Porto Alegre: Sérgio Antônio Fabris Editor, 1988.

DINAMARCO, Cândido Rangel. A instrumentalidade do processo. 15. ed. São Paulo: Malheiros, 2013.

FAVA, Marcos Neves. Ação civil pública trabalhista: teoria geral. 2. ed. São Paulo: LTr, 2008.

FRIGNANI, Aldo. L'injunction nella common law e l'inibitoria nel diritto italiano. Milão: Giuffrè, 1974.

GRINOVER, Ada Pelegrini. O processo em sua unidade. Rio de Janeiro: Forense, 1984.

LEITE, Carlos Henrique Bezerra. Curso de direito processual do trabalho. 5. ed. São Paulo: LTr, 2007.

LOPES, Teresa Ancona. Princípio da precaução e evolução da responsabilidade civil. São Paulo: Quartier Latin, 2010.

MANCUSO, Rodolfo de Camargo. Ação civil pública trabalhista: análise de alguns pontos controvertidos. Revista de Processo, São Paulo, ano 24, n. 93, p. 59, jan./mar. 1999.

MANCUSO, Rodolfo de Camargo. Acesso à justiça: condicionantes legítimas e ilegítimas. São Paulo: Revista dos Tribunais, 2011. 
MARINONI, Luiz Guilherme. Tutela inibitória: individual e coletiva. 5. ed. rev. São Paulo: Revista dos Tribunais, 2012.

MOREIRA, José Carlos Barbosa. Temas de direito processual: segunda série. 2. ed. São Paulo: Saraiva, 1988.

NERY JUNIOR, Nelson. Princípios do processo na Constituição Federal. 10. ed. rev., atual. e ampl. São Paulo: Revista dos Tribunais, 2010.

OLIVEIRA, Sebastião Geraldo de. Indenizações por acidente do trabalho ou doença ocupacional. 3. ed. São Paulo: LTr, 2007.

PIMENTA, José Roberto Freire. A tutela metaindividual dos direitos trabalhistas: uma exigência constitucional. In.: PIMENTA, José Roberto Freire; BARROS, Juliana Augusta Medeiros de; FERNANDES, Nadia Soraggi (Coord.). Tutela metaindividual trabalhista: a defesa coletiva dos direitos dos trabalhadores em juízo. São Paulo: LTr, 2009.

Tutelas de urgência no processo do trabalho: o potencial transformador das relações trabalhistas das reformas do CPC brasileiro. In.: PIMENTA, José Roberto Freire; RENAULT, Luiz Otávio Linhares; VIANA, Marco Túlio; DELGADO, Maurício Godinho; BORJA, Cristina Pessoa Pereira (coords.). Direito do trabalho: evolução, crise, perspectivas. São Paulo: LTr, 2004.

PISANI, Andrea Proto. Studi di diritto processuale del lavoro. Milão: Franco Angeli, 1976.

RAPISARDA, Cristina. Profili della tutela civile inibitoria. Padova: CEDAM, 1987.

SPADONI. Joaquim Felipe. Ação inibitória: a ação preventiva prevista no art. 461 do CPC. 2. ed. rev. e atual. São Paulo: Revista dos Tribunais, 2007.

SUÁREZ, Christian Delgado. O panorama atual e a problemática procedimental em torno da tutela inibitória. Revista de Processo, São Paulo, ano 38, n. 226, p. 283-321, dez. 2013.

TALAMINI, Eduardo. Tutela relativa aos deveres de fazer e de não fazer. São Paulo: Revista dos Tribunais, 2001.

Trabalho enviado em 21 de janeiro de 2017.

Aceito em 14 de abril de 2017. 